\title{
BRD9 Gene
}

National Cancer Institute

\section{Source}

National Cancer Institute. BRD9 Gene. NCI Thesaurus. Code C157083.

This gene plays a role in binding to acylated histones, chromatin remodeling and the regulation of transcription. 